\title{
Effect of foliar application of zinc and salicylic acid on growth, flowering and chemical constitute of African marigold cv. pusa narangi gainda (Targets erecta L.)
}

\author{
A. Choudhary, A. Mishra", P. K. Bola, S. K. Moond and M. Dhayal \\ Department of Floriculture and Landscaping College of Horticulture and Forestry, Agriculture University, \\ Jhalarapatan, Jhalawar, Kota -326023 (Rajasthan), INDIA \\ *Corresponding author. E-mail: Ashokchoudhary116@gmail.com
}

Received: January 04, 2016; Revised received: June 02, 2016; Accepted: August 05, 2016

\begin{abstract}
A field experiment on African marigold (Targets erecta L.) was conducted during winter season of 201415 to study the foliar effect of $\mathrm{Zn}$ and SA of 20 treatment combinations having five concentrations of zinc $(0.0,0.25$, $0.50,0.75$, and $1.0 \%$ ) and salicylic acid $(0.0,0.25,0.50$ and $1.0 \mathrm{mM} / \mathrm{L})$. The treatment $\mathrm{Zn}_{4} \mathrm{SA}_{3}$ (Zinc $1 \%+$ Salicylic acid $1.0 \mathrm{mM} / \mathrm{L})$ recorded the maximum plant height $(77.41 \mathrm{~cm})$, number of leaves per plant (314.10), earliest first flower bud appearance (39.78 days), maximum number of flowers per plant (62.33), maximum chlorophyll content $(3.83 \mathrm{mg} / \mathrm{g})$ and maximum carotene content $(3.07 \mathrm{mg} / \mathrm{g})$ as compared to control where it was recorded minimum. These results are conclusive that foliar spraying with zinc $1.0 \%$ + salicylic acid $1.0 \mathrm{mM} / \mathrm{L}$ may positively increasedthe growth and flowering parametersof marigold.
\end{abstract}

Keywords: African marigold, Pusa narangi gainda, Salicylic acid, Zinc

\section{INTRODUCTION}

African marigold (TageteserectaL.) belongs to family Asteracece is a very popular commercial flower crop as loose flower in Indiabecause of its wide adaptability to various soils, climatic conditions and easy cultivation. Marigold having ornamental, medicinal and industrialuses, it has additional use in controlling the soil nematodes. All varieties of marigold are resistant against root knot nematode, Meloidogyne incognita and could be used to control $M$. incognita in highly infested areas (Visser and Vythiunga, 1959; Natarajan et al., 2006). It is established fact that nutrition plays an important role in the improvement of growth, flowering andchemical constitute in marigold (Jayalakshmi et al., 2010).It is well known that Zinc acts as a cofactor of many enzymes and affects many biological processes such as photosynthetic reactions, nucleic acids metabolism, protein and carbohydrate biosynthesis. The role of Zinc in plant is due to its requirement in the synthesis of tryptophan which is a precursor of indole acetic acid (Shukla et al., 2009) and also activate the plant defense mechanism (Anuprita et al., 2005; Raut et al., 2014; Keram et al., 2014).The word salicylic acid (SA) was derived from Latin word "Salix", meaning willow tree. It is ubiquitously distributed in the whole plant kingdom and is classified under the group of plant hormones (Raskin et al., 1990). Exogenous application of Salicylic acid before reproductive stage may result in higher biomass production, disease resistant elicitors and increase in to total flavonoids content of marigold plants.
Foliar applicationconstitute the most effective means of micro-nutrient applications when problem of nutrient fixation in the soil exists. Therefore keeping this in view, the present experiment was initiated with an objective to study the effect of $\mathrm{Zn}$ and SA on flowering and yield of African marigold cv. PusaNarangiGainda to work out optimum dose of $\mathrm{Zn}$ and SA.

\section{MATERIALS AND METHODS}

The field experiment was carried out at the Instructional Farm, Krishi Vigyan Kendra, Jhalawar, during rabi season 2014-15. The soil had organic carbon 0.48 $\%$, (Walkley and Black,1934) available nitrogen $240.68 \mathrm{~kg} / \mathrm{ha}$ (Subbiah and Asija, 1956) available phosphorus $16.83 \mathrm{~kg} / \mathrm{ha}$ (Olsen et al., 1954) and available potash $299.0 \mathrm{~kg} / \mathrm{ha}$ (Metson, 1956) as standardized. One month-old seedlings of cv. Pusa Narangi Gainda were transplanted at the spacing of $30 \times 30 \mathrm{~cm}$ by drip irrigation in RBD factorial design. The observations on plant height, number of leaves/plant, days taken for first flower bud appearance, number of flowers per plant, carotene content $(\mathrm{mg} / \mathrm{g})$ and chlorophyll content $(\mathrm{mg} / \mathrm{g})$ were recorded(Wettstein, 1957, Sadasivam and Manickam, 1997 and Chaudhary et al., 2015).

Statistical analysis : The data generated from the present study were analyzed statistically and to draw suitable inference as per standard ANOVA technique described by Gomez and Gomez (1984).

\section{RESULTS}

The flowering and yield characters differed signifi- 
cantly for the various zinc, salicylic acid levels and interactions of $\mathrm{Zn} \times \mathrm{SA}$ (Table 1\&2). The maximum plant height $(74.06 \mathrm{~cm})$, number of leaves per plant (305.68), minimum days taken for first flower bud appearance (41.41 days), maximum number of flowers per plant (59.27), maximum (353.52 g), maximum carotene content $(3.02 \mathrm{mg} / \mathrm{g})$ and maximum chlorophyll content $\left(3.61 \mathrm{mg} / \mathrm{g}\right.$ ) at $\mathrm{Zn}_{4}$ (Zinc $\left.1.0 \%\right)$. while the minimum plant height $(55.01 \mathrm{~cm})$, number of leaves per plant (244.04), maximum days taken for first flower bud appearance (43.99 days), minimum number of flowers per plant (51.11) minimum carotene content $(2.73 \mathrm{mg} / \mathrm{g})$ and minimum chlorophyll content $\left(2.87 \mathrm{mg} / \mathrm{g}\right.$ ) were recorded with $\mathrm{Zn}_{0}$.

The maximum plant height $(67.42 \mathrm{~cm})$, number of leaves per plant (290.22), minimum days taken for first flower bud appearance (40.94 days), maximum number of flowers per plant (58.69), maximum carotene content $(2.89 \mathrm{mg} / \mathrm{g})$ and maximum chlorophyll content (3.44 mg/g)at $\mathrm{SA}_{3}$ (Salicylic acid $0.50 \mathrm{mM} / \mathrm{L}$ ). Similarly, the minimum days taken for first flower bud appearance (43.95 days), minimum number of flowers per plant (50.72), lowest chlorophyll content $(3.06 \mathrm{mg}$ / g) and minimum carotene content $(2.76 \mathrm{mg} / \mathrm{g})$ were recorded with $\mathrm{SA}_{0}$.

The interaction of $\mathrm{Zn} \& \mathrm{SA}$ had the maximum plant height $(77.41 \mathrm{~cm})$, number of leaves per plant (314.10),earliest first flower bud appearance (39.78 days), maximum number of flowers per plant (62.33), maximum carotene content $(3.07 \mathrm{mg} / \mathrm{g})$ and maximum chlorophyll content $(3.87 \mathrm{mg} / \mathrm{g})$ at $\mathrm{Zn}_{4} \mathrm{SA}_{3}$. While, the minimum plant height $(50.12 \mathrm{~cm})$, number of leaves per plant (189.78), longest first flower bud appearance (47.29 days), lowest chlorophyll content $(2.57 \mathrm{mg} / \mathrm{g}$ ) and minimum carotene content $(2.63 \mathrm{mg} / \mathrm{g})$ were recorded minimum number of flowers per plant (44.89) were recorded with control.

\section{DISCUSSION}

The increase in the growth characters with zinc and salicylic acid application might be attributed to synthesis of tryptophan which promotes intensity of auxins leading to more cell division and cell elongation, meristematic activity of the tissue and expansion of cells (Martin, 1966), enhanced the availability of macronu-

Table 1. Effect of Zinc and Salicylic acid on chemical constitute and growth of marigold.

\begin{tabular}{|c|c|c|c|c|}
\hline Treatments & Carotene(mg/g) & Chlorophyll (mg/g) & Plant height (cm) & Number of leaves per plant \\
\hline \multicolumn{5}{|l|}{ Zinc } \\
\hline $\mathrm{Zn}_{0}$ & 2.73 & 2.87 & 55.01 & 244.04 \\
\hline $\mathrm{Zn}_{1}$ & 2.76 & 3.08 & 59.74 & 254.20 \\
\hline $\mathrm{Zn}_{2}$ & 2.80 & 3.33 & 64.96 & 265.92 \\
\hline $\mathrm{Zn}_{3}$ & 2.85 & 3.45 & 69.84 & 288.50 \\
\hline $\mathrm{Zn}_{4}$ & 3.02 & 3.61 & 74.06 & 305.68 \\
\hline $\mathrm{CD}$ at $5 \%$ & 0.01 & 0.10 & 3.00 & 16.05 \\
\hline \multicolumn{5}{|l|}{ Salicylic acid } \\
\hline $\mathrm{SA}_{0}$ & 2.76 & 3.06 & 60.93 & 241.97 \\
\hline $\mathrm{SA}_{1}$ & 2.82 & 3.26 & 64.45 & 270.05 \\
\hline $\mathrm{SA}_{2}$ & 2.86 & 3.31 & 66.09 & 283.55 \\
\hline $\mathrm{SA}_{3}$ & 2.89 & 3.44 & 67.42 & 290.22 \\
\hline $\mathrm{CD}$ at $5 \%$ & 0.01 & 0.09 & 2.68 & 14.35 \\
\hline \multicolumn{5}{|l|}{ Interaction } \\
\hline $\mathrm{Zn}_{0} \mathrm{SA}_{0}$ & 2.63 & 2.57 & 50.12 & 189.78 \\
\hline $\mathrm{Zn}_{0} \mathrm{SA}_{1}$ & 2.71 & 2.85 & 54.24 & 245.88 \\
\hline $\mathrm{Zn}_{0} \mathrm{SA}_{2}$ & 2.77 & 2.97 & 56.62 & 269.69 \\
\hline $\mathrm{Zn}_{0} \mathrm{SA}_{3}$ & 2.80 & 3.08 & 59.06 & 270.81 \\
\hline $\mathrm{Zn}_{1} \mathrm{SA}_{0}$ & 2.70 & 2.90 & 56.77 & 208.92 \\
\hline $\mathrm{Zn}_{1} \mathrm{SA}_{1}$ & 2.72 & 3.03 & 59.60 & 257.88 \\
\hline $\mathrm{Zn}_{1} \mathrm{SA}_{2}$ & 2.79 & 3.11 & 60.84 & 270.81 \\
\hline $\mathrm{Zn}_{1} \mathrm{SA}_{3}$ & 2.83 & 3.26 & 61.73 & 279.38 \\
\hline $\mathrm{Zn}_{2} \mathrm{SA}_{0}$ & 2.73 & 3.15 & 61.28 & 242.81 \\
\hline $\mathrm{Zn}_{2} \mathrm{SA}_{1}$ & 2.81 & 3.35 & 64.96 & 262.65 \\
\hline $\mathrm{Zn}_{2} \mathrm{SA}_{2}$ & 2.83 & 3.36 & 66.23 & 276.04 \\
\hline $\mathrm{Zn}_{2} \mathrm{SA}_{3}$ & 2.84 & 3.47 & 67.35 & 282.18 \\
\hline $\mathrm{Zn}_{3} \mathrm{SA}_{0}$ & 2.79 & 3.23 & 68.21 & 268.89 \\
\hline $\mathrm{Zn}_{3} \mathrm{SA}_{1}$ & 2.86 & 3.48 & 69.02 & 287.43 \\
\hline $\mathrm{Zn}_{3} \mathrm{SA}_{2}$ & 2.89 & 3.50 & 70.55 & 293.08 \\
\hline $\mathrm{Zn}_{3} \mathrm{SA}_{3}$ & 2.88 & 3.58 & 71.56 & 304.61 \\
\hline $\mathrm{Zn}_{4} \mathrm{SA}_{0}$ & 2.97 & 3.43 & 68.22 & 299.46 \\
\hline $\mathrm{Zn}_{4} \mathrm{SA}_{1}$ & 3.01 & 3.59 & 74.44 & 300.81 \\
\hline $\mathrm{Zn}_{4} \mathrm{SA}_{2}$ & 3.03 & 3.63 & 76.18 & 308.33 \\
\hline $\mathrm{Zn}_{4} \mathrm{SA}_{3}$ & 3.07 & 3.83 & 77.41 & 314.10 \\
\hline $\mathrm{CD}$ at $5 \%$ & 0.03 & 0.21 & NS & 32.10 \\
\hline
\end{tabular}


A. Choudhary et al. / J. Appl. \& Nat. Sci. 8 (3): 1467 - 1470 (2016)

Table 2. Effect of zinc and salicylic acid on flowering parameter of marigold.

\begin{tabular}{|c|c|c|}
\hline Treatments & First flower bud appearance (DAT) & Number of flowers per plant \\
\hline \multicolumn{3}{|l|}{ Zinc } \\
\hline $\mathrm{Zn}_{0}$ & 43.99 & 51.11 \\
\hline $\mathrm{Zn}_{1}$ & 42.94 & 53.48 \\
\hline $\mathrm{Zn}_{2}$ & 42.68 & 54.38 \\
\hline $\mathrm{Zn}_{3}$ & 41.70 & 56.98 \\
\hline $\mathrm{Zn}_{4}$ & 41.41 & 59.27 \\
\hline $\mathrm{CD}$ at $5 \%$ & 0.91 & 2.05 \\
\hline \multicolumn{3}{|l|}{ Salicylic acid } \\
\hline $\mathrm{SA}_{0}$ & 43.95 & 50.72 \\
\hline $\mathrm{SA}_{1}$ & 42.95 & 54.04 \\
\hline $\mathrm{SA}_{2}$ & 42.35 & 56.69 \\
\hline $\mathrm{SA}_{3}$ & 40.94 & 58.69 \\
\hline $\mathrm{CD}$ at $5 \%$ & 0.82 & 1.83 \\
\hline \multicolumn{3}{|l|}{ Interaction } \\
\hline $\mathrm{Zn}_{0} \mathrm{SA}_{0}$ & 47.29 & 44.89 \\
\hline $\mathrm{Zn}_{0} \mathrm{SA}_{1}$ & 43.72 & 50.60 \\
\hline $\mathrm{Zn}_{0} \mathrm{SA}_{2}$ & 42.98 & 53.52 \\
\hline $\mathrm{Zn}_{0} \mathrm{SA}_{3}$ & 41.99 & 55.42 \\
\hline $\mathrm{Zn}_{1} \mathrm{SA}_{0}$ & 44.10 & 49.50 \\
\hline $\mathrm{Zn}_{1} \mathrm{SA}_{1}$ & 43.41 & 52.46 \\
\hline $\mathrm{Zn}_{1} \mathrm{SA}_{2}$ & 42.56 & 54.98 \\
\hline $\mathrm{Zn}_{1} \mathrm{SA}_{3}$ & 41.70 & 56.98 \\
\hline $\mathrm{Zn}_{2} \mathrm{SA}_{0}$ & 43.84 & 50.28 \\
\hline $\mathrm{Zn}_{2} \mathrm{SA}_{1}$ & 43.33 & 53.45 \\
\hline $\mathrm{Zn}_{2} \mathrm{SA}_{2}$ & 42.45 & 55.89 \\
\hline $\mathrm{Zn}_{2} \mathrm{SA}_{3}$ & 41.10 & 57.89 \\
\hline $\mathrm{Zn}_{3} \mathrm{SA}_{0}$ & 42.35 & 52.26 \\
\hline $\mathrm{Zn}_{3} \mathrm{SA}_{1}$ & 42.24 & 55.96 \\
\hline $\mathrm{Zn}_{3} \mathrm{SA}_{2}$ & 42.10 & 58.84 \\
\hline $\mathrm{Zn}_{3} \mathrm{SA}_{3}$ & 40.14 & 60.84 \\
\hline $\mathrm{Zn}_{4} \mathrm{SA}_{0}$ & 42.17 & 56.67 \\
\hline $\mathrm{Zn}_{4} \mathrm{SA}_{1}$ & 42.05 & 57.75 \\
\hline $\mathrm{Zn}_{4} \mathrm{SA}_{2}$ & 41.67 & 60.33 \\
\hline $\mathrm{Zn}_{4} \mathrm{SA}_{3}$ & 39.78 & 62.33 \\
\hline $\mathrm{CD}$ at $5 \%$ & 1.83 & 3.96 \\
\hline
\end{tabular}

trients (Chattopadhyay, 1994; Keram et al., 2014) and also increased number of internodes (Jaiwal and Bhambie, 1989). The salicylic acid could be attributed to its bio regulator effects on physiological and biochemical processes in plant and increased the number of nodes in plant (El-Tayeb, 2005). The present results are in conformity with the results of Pacheco et al. (2013) in marigold, Sharma et al. (2013) in gladiolus and Anwar et al. (2014) in tuberose. The increase in the flower characters with zinc and salicylic acid application might beattributed to more tryptophan production which acts as a precursor of auxin which increases the vegetative growth and leads to production of more food material, which in turn might have been utilized for better development of flowers (Muthumanickam, 1999). The salicylic acid might have altered the biophysical properties of cell wall and also there is a synergistic effect of salicylic acid and auxins (Padmapriya and Chezhiyan, 2002). The present results are in conformity with the results of Singh et al. (2012) in gladiolus, Pacheco et al. (2013) in marigold and An- war et al. (2014) in tuberose. Days taken for first flower bud appearance may be due to zinc which acts as a co-factor of many enzymes and affects many biological processes thereby induces early flowering (ElSeifi and Esmael, 1997) While, the salicylic acid functioned as endogenous growth regulator of flowering as florigenic effects (Raskin et al., 1992). The findings of this investigation are in line with of Pacheco et al. (2013) in marigold.

Maximum number of flower per plant might be due the application of zinc and salicylic acid which plays vital role for extended vegetative growth, pollen function, fertilization, metabolism of RNA, proteins and DNA formation (Pandey et al., 2006).Similar results are also reported by Reddy and Rao (2012) in gerbera.

The application of zinc and salicylic acid provided maximum chlorophyll content due to stimulative effect of salicylic acid and zinc causing antioxidantal scavenging effect to protect chloroplasts (Bowler et al., 1992). The increase in carotene content with salicylic acid and zinc might be attributed to the effect of these 
substances on the biosynthesis of secondary metabolites and enhancing the photosynthetic activity in marigold (Kim et al., 2009). Similar results were also reported by El-Naggar (2005) in gladiolus and Pacheco et al. (2013) in marigold.

It is evident that the foliar spraying with zinc $1.0 \%+$ salicylic acid $1.0 \mathrm{mM} / \mathrm{L}$ may positively regulated the marigold growth, flowering and chemical constitute thus improved the production.

\section{REFERENCES}

Anuprita, H., Jadhav, S. R., Dalal, R. D. and Rajeshwari, P. 2005. Effect of micronutrients on growth and flower production of Gerbera under poly house conditions. $A d v$. Sci., 18 (11): 755-758.

Anwar, M., Sahito, H. A., Hassan, I.,Abbasi, N. A. and Abro, H. A. 2014.Effect of pre harvest treatment of salicylic acid on growth and vase life of tuberose with aroma environment. J. Agric. Res.,3(2): 50-57.

Bowler, C., Montoguand, M. V. and Inze, D. 1992. Superoxide dismutase and stress t o 1 e r ance.Ann. Rev. Plant Physiol. Pl. Mol. Bio.,48: 223-250.

Chattopadhyay, P. K. 1994. A Text Book of Pomology.Kalyani Publishers, B I/1292, Rajendra Nagar, Ludhiana, Punjab, India, pp. 144-181.

Chaudhary, A. Mishra, A. Nagar, P.K and Chaudhary, P. 2015.Effect of Foliar Application of Zinc and Salicylic Acid on Floweringand Yield of African Marigold cv. Pusa Narangi Gainda. Hortflora Res.Spect.4(4):351-355.

El-Naggar, A. H. 2009. Response of Dianthus caryophyllusL. plants to foliar nutrition. J. Agric. Sci.,5(5): 622-630.

El-Seifi, S. K. and Esmael, A. E. 1997.Okra seed production and seed quality asinfluenced bysowing date and zinc and $\mathrm{GA}_{3}$ treatments.Egypt. J. Appl. Sci., 12: 277-289.

El-Tayeb, M. A. 2005. Response of barley grains to the interactive effect of salinity and salicylic acid. Plant Growth Regulation, 45: 215-224.

Jaiwal, P. K. K. and Bhambie, S. 1989. Effect of growth regulating substances on podand yield of Vignaradiata L. ActaBotani.Indica, 17: 54-80.

Gomez, K. A. and Gomez, A. A. (1984).Statistical procedures for Agricultural Research. $2^{\text {nd }}$ Edn., John Wiley and Sons. Inc. New York, USA.

Jayalakshmi, P., Suvarnalatha devi, P., Prasanna, N. D., Revathi, G.and Shaheen , S. K. 2010. Morphological and physiological changesof Groundnut plants by foliar application with salicylic acid. TheBioscan, 5(2): 193-195.

Keram, K. S., Sharma, B.L., Sharma, G.D. and Thakur, R.K. 2014. Impact of zinc application on its translocation intovarious plant parts of wheat in a vertisol.The Bioscan, 9(2): 491-49.

Kim Y. H., Hamayun, M., Khan, A. L., Kang, S. M. and Han, H. H. 2009. Exogenous applicationof plant growth regulators increased the total flavonoid content in Taraxacum officinale.African J. Bio., 8: 5727-5732.

Martin, J. A. 1966. Greenhouse fertilizer trial of bean in tarai
soil.RicaiGourTuvrial., 17: 411-418.

Metson, A. J. 1956. Methods of chemical analysis for soil survey samples. Department of Science Md. Res. Soil Bur.Pp. 12.

Muthumanickam, O., Rajamani, K. and Jawaharlal, M. 1999. Effect of micro-nutrients on

Flower production in gerbera. J. Orn. Hort., 2(2): 131-132.

Natarajan, N., A. Cork, N. Boomathi, R. Pandi, S. Velavan, and Dhakshnamoorthy. G. $2006 . \quad$ Cold aqueousextracts of African marigold, Tagetes erecta, forcontrol of tomato root knot nematode, Meloidogyne incognita. Crop Protection25: 1210-1213.

Olsen, S. R., Cole, C. S., Wantable, F. S. and Dean, C. A., 1954.Estimation of available phosphorus in soils by extraction with sodium bicarbonate U.S.D.A., Washington, D.C. Circular.18: 939.

Pacheco, A. C., Cabral, C. S., Fermino, E. S. S. and Aleman, C. C. 2013. Salicylic acid-inducedchanges to growth, flowering and flavonoids production in marigold plants. J. Medi. Pl.Res., 7(42): 3162-3167.

Padmapriya, S. and Chezhiyan, N. 2002. Influence of gibberellic acid and certain other chemicalson flowering characters of chrysanthemum (Dendranthemagrandiflora) cultivars. SouthIndian Hort.,50(4-6): 437-443.

Pandey, N., Pathak, G. C. and Sharma, C. P. 2006. Zinc is critically required for pollen function andfertilization in lentil. J. medi.bio. Sci., 20: 89-96.

Raskin, I. 1992. Role of salicylic acid in plant.Annu. Rev. Pl. physiol. Pl. Mol.,(43): 439-463.

Raskin, I., Skubatz, H., Tang, W. and Meeuse, M. J. D. 1990. Salicylic acid levels in thermogenicand nonthermogenic plants. Ann. Bot, 66: 376-383.

Raut, S. A., Borkar, S. G. and Nagrale, D. T. 2014. Effect of disease (alternaria leaf blight) resistanceelicitors on growth parameters of tomato plant. The Bioscan.9(3): 1157-1159.

Sadasivam, S. and Manickam, A. (1997).Biochemical Methods ( $2^{\text {nd }}$ edition). New International Publishers Limited, New Delhi.

Shukla, A. K., Dwivedi, B. S., Singh, V. K. and Gill, M. S. 2009. Macro Role of Micro-nutrients. Indian J. Ferti.,5 (5): 27-30.

Singh, J. P., Kumar, K. and Katiyar, P. N. 2012. Effect of zinc, iron and copper on yield parameters of gladiolus. HortFlora Res. Spect., 1(1): 64-68.

Subbiah, B.V. and Asija, G.L. (1956).A rapid procedure for the estimation of available nitrogen in soils.Current Sci., 126: 244-253.

Walkley, A. and Black, I. A. (1934). An examination of Degtjareff method for determining soil organic matter and a proposed modification of the chromic acid titration method. Soil Sci., 37:29-37.

Wettstein, D. (1957). Chlorophyll - letaleunddersubmikroskopischeFormwechsel der Plastiden.Exp. Cell Res., 12, 427-487.

Visser, T. and Vythiunga M. K., 1959. The effect of marigolds and someother crops on the Pralylenchus and Meloidogyne populations in tea soil. Tea Quart.30: 30-38. 